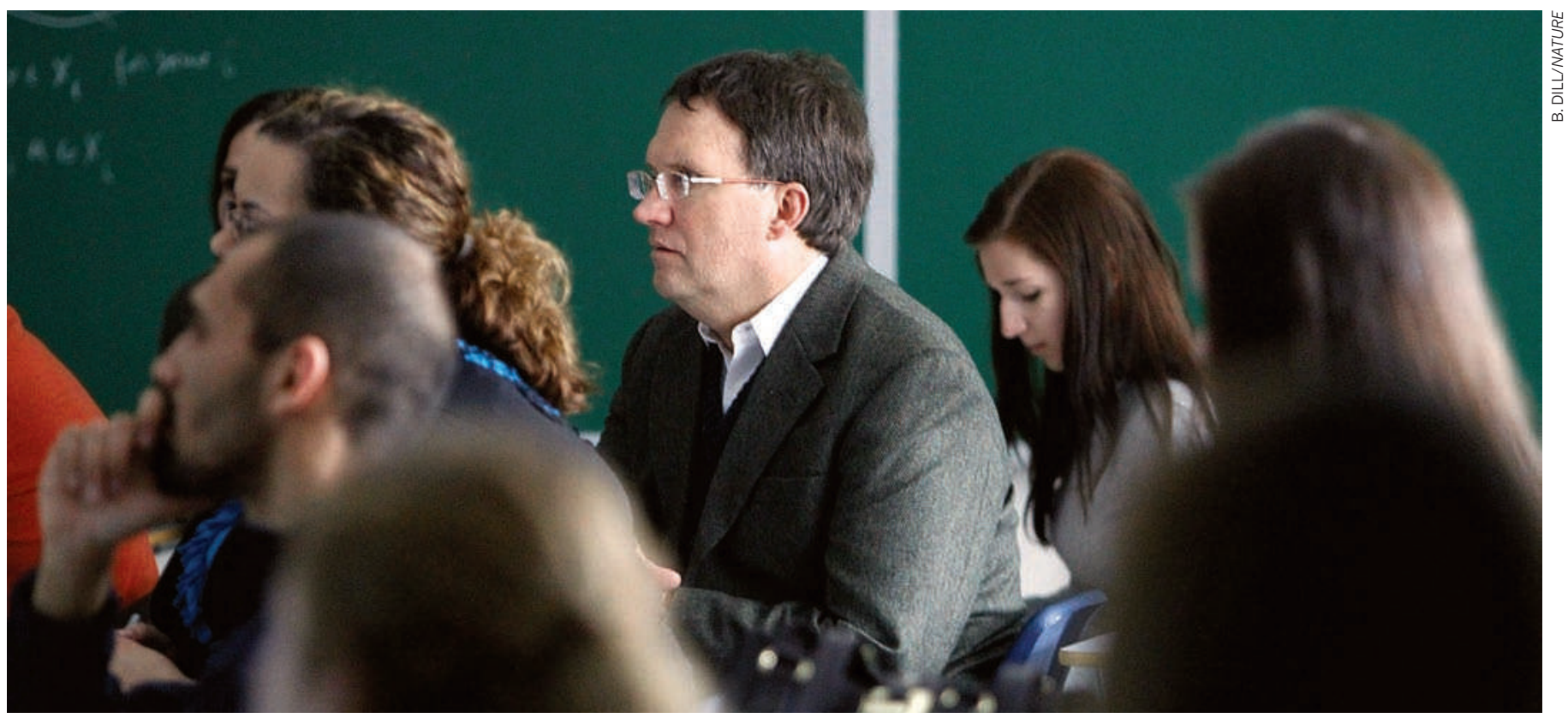

Joseph Leahy (centre), critically wounded a year ago, is back on campus nearly every day.

COMMUNITY

\title{
University seeks to emerge from shooting's shadow
}

\section{One year after an assistant professor murdered three colleagues at the University of Alabama in Huntsville, researchers are striving for a new 'normal'.}

\section{BY MEREDITH WADMAN}

$\mathrm{U}$ nder normal circumstances it would have been a year of modest successes for a small but ambitious biology department. A new confocal microscope is up and running; spring enrolment is up, four $\mathrm{PhD}$ candidates are expected to graduate and, last month, the Carnegie Foundation, which classifies institutions of higher education in the United States, changed its rating of research activity on campus from 'high' to 'very high'.

But for the biology department at the University of Alabama in Huntsville (UAH), such achievements stand in a more heroic light. Just one year ago, on 12 February 2010, biologist Amy Bishop opened fire with a 9-millimetre pistol during a faculty meeting, killing three department members and critically wounding two others (see Nature 465, 150-155; 2010). A third sustained a less-serious injury. Now, the department is labouring to regain its balance, coping with the logistics of rebuilding and with the legal fallout from the tragedy.

On Saturday, members of the UAH community will gather to mark the anniversary of the shooting with a service of 'remembrance and renewal'. Students and faculty members will speak about the legacy of the fallen: plant biologist Maria Ragland Davis; physiologist Adriel Johnson; and Gopi Podila, a plant molecular biologist who was chairman of the biology department. They will also pay tribute to the survivors: microbiologist Joseph Leahy and staff assistant Stephanie Monticciolo, both still recovering from grievous injuries. Others - including the rest of the biology faculty, nearly all of whom were gathered around the table in the small conference room where the shootings occurred - nurse wounds that are not as visible.

The university is at pains to note that the service will look forwards as much as back. "The event is part of our history. We cannot take it away," UAH president David Williams told Nature last week. "But we will not let it define the university."

For the 12-member biology faculty, the goal "is to be at a point where we are recognized not as a department of tragedy,

\section{ONATURE.COM}

The aftermath of the Huntsville massacre:

go.nature.com/qltvmy but as a department of academic excellence", says Joseph Ng, a structural biologist who witnessed the shootings.

$\mathrm{Ng}$, who is leading the search to permanently fill the vacant positions, points to signs of progress. As of last week, he had received nearly 200 applications for three tenure-track positions that will help to restore the department to full strength. For now, visiting professors are teaching the physiology, cell biology and microbiology that had been taught by Bishop, Davis, Johnson and Leahy. Colleagues are shepherding the last months of funding from grants that belonged to the slain biologists. The new confocal microscope for which Podila and Davis had won funding is in use. And Debra Moriarity, a biologist who had been graduate dean at UAH, has taken over as interim chair of the department, after a collective decision to delay the search for a permanent chair. Moriarity, who crawled under the conference table and grabbed Bishop by the leg to try to stop her shooting, says that the toughest thing she has had to do in recent months is to move into Podila's office, packing up his stuff. "We are trying to figure out what the new 'normal' is," she says. 
Although Bishop has not yet been indicted for the shootings, a violent personal history has emerged that has continued to cast a shadow over UAH's efforts to recover. In June, a Massachusetts grand jury charged Bishop with fatally shooting her brother in 1986, an act that had originally been ruled an accident. Last month, the spouses of Johnson and Davis filed a 'wrongful death' lawsuit against Bishop, her husband James Anderson and UAH provost Vistasp Karbhari. It alleges that Karbhari was "directly aware of Bishop's emotional instability" and failed to implement a university safety policy that would have required contacting police or counselling services. (Leahy, Monticciolo and their spouses filed a suit against Bishop and Anderson, without naming Karbhari, in November.)

The university has responded in a statement that it "will vigorously defend" the lawsuit. It adds that it "is saddened by the decision to sue Dr. Vistasp Karbhari and does not agree that Dr. Karbhari, or anyone associated with the university, could have predicted or prevented this random act of violence".

The return of Leahy has been an inspiration to faculty members and students. Bishop fired her last bullet at him before her gun jammed, shattering his forehead and severing his right optic nerve; today he is blind in his right eye and has partial vision in his left. The bullet remains

lodged in his neck, too close to the jugular vein to remove safely. A metal plate inserted to replace part of his skull became infected last autumn and had to be removed, leaving a baseball-sized indentation in his forehead. Another operation will be required to insert a new plate. Until that happens, falling and injuring the underlying brain remains a significant risk.

Nonetheless, Leahy,

"You come to grips with the fact that it has happened. You just want to make sure that it doesn't defeat you." who has no memory of the shooting, is now on campus almost every day, when he is not at one of the innumerable therapy sessions speech, vision, physical and occupational - that have consumed the past year. He lifts weights or runs at the fitness centre; works in his office, where an extra-bright lamp has been installed; and assists with a class being taught by Moriarity for aspiring health-profession students, whom he has also begun advising - a job that had been Johnson's. He has tentative okays from Moriarity and the dean of science to return to work full time in the autumn.

Not for a moment did he think of leaving biology, says Leahy, an expert in the bacterial degradation of hydrocarbons. "This is who I am. This is what I do."
"I find him incredibly inspirational: 'Yes, I have a huge crater in my head, but it is what it is and life goes on'”, says Leland Cseke, a research professor who saw Bishop rush down the hall as she fled after the shootings. "When you see him, you just have a good feeling."

Bishop, in the meantime, awaits her fate in the Madison County jail. She stands charged with one count of capital murder - murdering two or more people at the same time is a capital offence in Alabama - and three counts of attempted murder. A grand jury is likely to hear the facts of the case in the coming weeks. In Alabama, capital murder is punishable by life in prison without parole or by the death penalty. Robert Becher, the chief trial attorney for the Madison County District Attorney's Office, who is prosecuting the case, says that the state has not yet decided which punishment to seek.

Back on campus, another decision is pending: what to do with the conference room where the shootings occurred, which remains closed and locked. It may be converted into an open gathering space. Or it may be reconstituted as a conference room, says Moriarity, "so it doesn't look the same but could still be used - with two doors".

Moving forward, with a focus on rebuilding, is vital, says Ng. "You come to grips with the fact that it has happened. You just want to make sure that it doesn't defeat you." 